\title{
Peter I and the Birth of the Russian Empire: Political Leadership and Military Successes in Comparative Perspective
}

\author{
A. Dimitrov 1 , G. Durev² \\ ${ }^{1}$ University of National and World Economy (Bulgaria) \\ ${ }^{2}$ Sofia University St. Kliment Ohridski (Bulgaria)
}

\begin{abstract}
Empires are usually born through political recognition and extensive military successes. The ruler's personality and the activities of political and military advisors and generals are crucial for the emergence of an empire. The authors argue that in the case of Peter the Great (Peter I), the political recognition and military successes were achieved simultaneously in the east and west, however, in different contexts. The authors make a series of comparisons between Peter I and other monarchs of the epoch, such as Carl XII, August II, Frederick I, Carlos II, Willem III, Leopold VI, and others, relying on three main categories, namely education, "vices and virtues" and political views. This comparison is necessary to highlight the essential prerequisites in Peter's personal development that might have determined his political actions. In addition, the article carries out an evaluation of the geopolitical significance of the military campaigns and victories achieved by the tzar and his commanders. These achievements are substantiated to correlate with Russian rise as a great power directly. After the Peace of Nystad, the geopolitical interests of the Tsardom were finally met, with the territorial dominium of the Empire being outlined for a century ahead.

Furthermore, the territorial expansion was accompanied by the exercise of the "imperium" as a political authority exclusive to the Russian monarchs. The authors try to highlight the connection between the personal development of monarchs, their achievements, and imperial ambitions. The comparative analysis of these factors in various imperial cases provides additional considerations for understanding the historical period.
\end{abstract}

Keywords: Peter I, imperium, leadership, geopolitics, war, Peace of Nystad, the Great Northern War

W hat is essential to create an empire is one of the key questions of the current research. There are various definitions for "empire." It usually refers to a major political unit where the metropolis or other sovereign authority exercises control over the territory of a great extent or several regions or 
peoples through formal annexations or various types of informal domination ${ }^{1}$. Another definition states that it is an extensive territory under the control of a supreme ruler (typically an emperor) or an oligarchy, often consisting of an aggregate of many separate states or territories; or, in later use: an extensive group of subject territories under the rule of a single sovereign power ${ }^{2}$. Therefore, an empire is underpinned by two equally necessary elements: vast territory and ruling authority. In the case of Russia at the end of the $17^{\text {th }}$ century, the territory as a critical element was already present. The biggest part of Siberia was conquered by the Tsardom between the mid$16^{\text {th }}$ and mid- $17^{\text {th }}$ centuries. When Peter I came to power, the Russian Tsardom was far more extensive than most European states. Indeed the territory by itself is not enough for a state to be recognized as an empire. There is also a vital need to recognize the imperial authority of the sovereign. Such a condition is essential because of the basic imperial pattern established in Europe. This is the model that emerged in the Roman Empire, where the emperor's power was total, with his authority extending unconditionally to both the army and the political institutions. This model survived after the Empire's collapse granting even more powers to the Byzantine emperors.

The key term in this context is "imperium." In the broadest sense, imperium refers to the scope of power over something (process, institution, etc.) or someone (hierarchical subordination). Still, we usually mean the Roman usage mentioned above when it comes to monarchical power. Here imperium denotes a dual capacity: to wage wars and make and execute laws. An "emperor" was originally a victorious general, later a supreme magistrate, but it also came, even in late Republican Rome, to have a different connotation: the size of the territory. Imperium meant to rule over extensive, far-flung spaces, far beyond the original "homeland" of the rulers (Howe 2002: 14). Peter I followed an even more strict formula than that of the Eastern Roman Empire, so the imperium of the monarch was superior to all (except God): the formula basileús [kai] autokrátōr (emperor and autocrat).

To achieve such an imperial status, Peter I understood that he had to be recognized by all other monarchs of the same imperial status in Europe. Such recognition must have been achieved simultaneously on the battlefield through military victories and politically through appraisal of his political leadership. Paraphrasing Sarolta Takacs, to sustain an empire (in the Roman sense), a successful leader displays virtues ${ }^{3}$ to secure loyalty and employs rhetorical discourse grounded in traditional virtues (the mos maiorum) accepted by the ancient Romans. The most virtuous leaders received the

\footnotetext{
1 O'Neil D. Empire. Encyclopedia Britannica. 2021. URL: https://www.britannica.com/topic/empire-political-science (accessed 01.11.2021)

2 Empire. Oxford Dictionary Online. 2021. URL: https://www.oed.com/view/Entry/61337?rskey=ZzCRVM\&result=1\&isAdva nced=false\#eid (accessed 01.11.2021)

3 In this case - virtue, manliness, moral stature, courage, and other qualities.
} 
honorific "father of the country" (pater patriae) and could claim divine favor (Takacs 2009: XVIII $)^{4}$.

In the article, it is substantiated that the forging of an empire requires territorial expansion, meaningful military successes, and visionary political leadership, whose understanding remains impossible if not put into the historical context that is, in this research, the last quarter of the $17^{\text {th }}$ century and the beginning of the $18^{\text {th }}$ century.

\section{The epoch of Peter I}

The life of Peter I and his rise to power are marked by a few significant characteristics. Most authors state that the foundations of the Russian Empire were built during the first Romanovs - Michael, Alexis, and Fyodor III ; the most essential condition here was the overcoming of the devastation during the Time of Troubles. As Shmurlo writes, "the wounds of the period must be healed - the country is in ruins and impoverished; the treasury is empty and cannot meet the needs of the state; the ruling authority is diminished; the outside threats are rising" (Шмурло 2008: 203). At the regency of Sophia, most of the "wounds" were to some extent healed, but Russia, despite the territorial expansion, lacked development and cultural progress. Here is the second crucial characteristic of the period: the young tsar was aware of the situation; he understood the obsolescence of the old ways and the need for reform but lacked the knowledge and authority to implement changes (Soloviev 1994: XV). For that reason, the Great Embassy as a reflection of this understanding is reviewed in detail hereafter. The third important point is the existence of three major venues of the imperial foreign policy - the Baltic, the Black sea, and the Polish ones (Шмурло 2008: 204). These directions eventually led to the Russo-Turkish War (1686-1700), The Great Northern War (1700-1721), and the struggle against the Polish ambitions in Eastern Europe.

The Peace of Westphalia put an end to the Thirty Years' War and unleashed serious centrifugal processes in all parts of the Holy Roman Empire. At the end of the century, the Swiss Confederation and the Netherlands left the Empire; Austria was getting stronger and, together with the Polish-Lithuanian Commonwealth defeated the Ottoman Turks in Vienna; Prussia was also gaining independence as a sovereign entity. The Holy Roman Empire no longer existed with its former splendor and power. Instead, there was rather a fragile confederation of different units held together by the authority of the Habsburgs (Bryce 1901: 343-345). This led to the rise of Brandenburg Prussia and eventually to the formation of the Austrian Empire later on - diplomatic rivals and allies of the Russian Empire during the next 200 years (Figure 1).

\footnotetext{
4 It must be noted that with the emerging of Christianity Christ was referred as King of Kings and in that sense the divine imperium was understood - rule over all divine and earthly.

5 Russian Empire. 2021. Britannica, Encyclopaedia. URL: https://www.britannica.com/place/Russian-Empire (accessed 01.11.2021)
} 


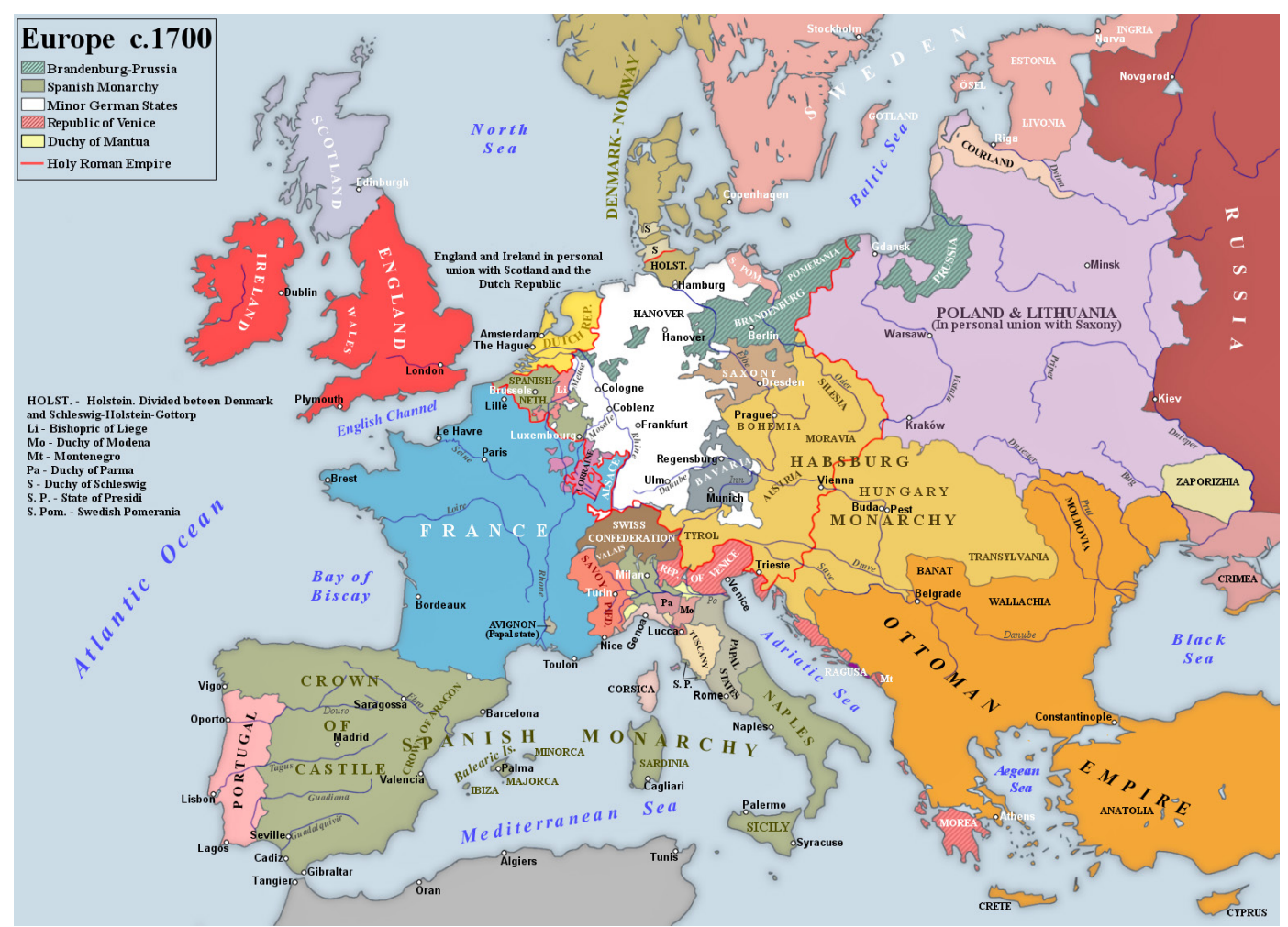

Figure 1. Europe at the beginning of the $18^{\text {th }}$ century

Source: Wikimedia Commons, author: Rebel Redcoat

After Westphalia, the Great Elector Frederick William I started a vast (protestant in spirit) reconstruction of the state. He built a state based on order, a militaristic and bureaucratic regime, which would earn him widespread respect (Shennan 1995: 29). He indeed laid down the foundations of the modern (at the time), centralized and unitary state (Gesamtstaat), but also bound to the tradition of nobility, an absolutist, and to some point, old-style dynast (Shennan 1995: 39). In the consequent Nine-Years' War and the following diplomatic maneuvers, Frederick III (later King Frederick I) demonstrated that Prussia would play a significant role during the next century.

The Peace of Westphalia also reinforced the Habsburg separatism and fostered the independent development of Austrian lands. At the same time, as holy emperor and sovereign of the Austrian lands, Leopold I provided new guidance for the old imperial institutions. His efforts were partially successful: the imperial political institutions began to be reformed and renewed; the changes made the Viennese court an even stronger center of attraction for the Reich's nobility. It begot continuous stability and a series of domestic and foreign successes (mainly during Leopold's reign) (Whaley 2012: 7).

In the same period, one of the most important issues for Russia were the relations with the Polish-Lithuanian Commonwealth, where King Jan III Sobieski gained momentum as a defender of the faith, victorious warrior against Ottomans, and bold 
reformer. At the same time, the Polish Commonwealth was divided. In socio-political terms, the Polish state could not resolve the contradictions between modern and national perceptions of one part of society and the religious, archaic, and hierarchical views of the other (Zamoyski 2014). Usually mentioned as one of the last true kings of Poland, despite his efforts, Jan III Sobieski failed to revive Poland as a great power. The nobility opposed his reforms (especially the liberum veto) and the centralization of royal power (including the hereditary principle). The crisis after his death deepened the political anarchy and economic ineffectiveness (Stiles 1999: 727).

Prussia, Austria, and Poland were of vital interest for the Russian foreign policy and the states of Western Europe: France of Louis XIV, the Netherlands of William III of Orange, who was also the king of England, and Spain of Charles II. Different styles of rule characterized the three monarchs. William III tried to balance between the crown and parliament in England and between kingship and the citizen status of stadtholder in the United Dutch Republics. France of Louis XIV was the most populated and one of the most prosperous European countries. With the unmatched presence of its king and his international prestige, modern and capable army, a booming economy, and widespread cultural influence, France stayed a leading country.

On the contrary, Charles II was the last Habsburg to rule Spain since his reign was disastrous for the Empire. After his death, Spain remained the great power only on paper, without an undisputed successor to the throne, a ruined treasury (troubled with heavy loans), a small and demoralized army, and a disorganized fleet unable to defend its territories outside mainland Spain.

These developments determined the international environment for Russia when Peter I came to power and later during the military confrontation with the Ottoman Empire and the Kingdom of Sweden. At the same time, the vast Ottoman Empire was no longer the power that existed in the previous century: new tactics, military engineering, and training could fight easily against massive but less modernized armies. The Swedish aristocracy and its young king Carl XII understood that, but Peter I and his counselors realized that even earlier and the need for modernization of the Russian army. That reason - looking for advanced knowledge, experience, and know-how - was one among the most important in the organization of the Grand Embassy. However, there was one more reason: the opportunity to study European monarchies more precisely in practice and personally, especially in terms of their authority, prestige, and political leadership patterns.

\section{The political leadership of Peter I and his fellow monarchs}

While considering imperial leadership, one usually refers to the Roman period. Still, the truth is that every epoch has its standards, and that should be considered while comparing them. Most of the European rulers fall in the category of "heroic leadership," which is not surprising. Heroism has had significant importance for every epoch from classical antiquity till now; historians even proposed the first official lead- 
ership theory, "The great man theory." In 1841 Thomas Carlyle wrote the book "On Heroes, Hero-Worship and the Heroic in History," and several years later, Francis Galton strongly influenced the trait theory through his two books "Hereditary Genius" and "Noteworthy Families." Indeed, Carlyle's work was rather "history of the great men" than a strict concept. Still, as a competent historian, Carlyle gave his audience a remarkable panorama of hero-worship through the ages but also in different perspectives - the hero as divinity, as a prophet, as a poet, a priest, a man of letters, and as a king (Dimitrov 2020: 68). Perceiving a ruler as an enlightened autocrat was not usual for ordinary people who tended to see in their "tsar" something extraordinary, even legendary, as they perceived Ivan Tsarevich and his heroic doings or Prince Vladimir Bright Sun (Seal 2001). However, it was not the same for aristocratic circles and courts in Europe. The authors of the early 16 century paved the road to a new image of the ruler and emperor. John Skelton, Erasmus, Machiavelli, and Antonio de Guevara created a unique formula enhancing the old concept of the divine mandate and new leadership standards for their sovereigns (like Henry VIII, Charles V, Lorenzo di Medici, etc.). The kings and emperors must have obtained more knowledge of the past and present, generated multiple ways to understand their realm, and acted accordingly. The monarch's person was still sacred, but the importance of knowledge exceeded the significance of divine blessing (Dimitrov 2020: 78). More or less, this concept of the enlightened autocrat remained unchanged throughout the 17 century.

Therefore, the Great Embassy cannot be understood historically only as a diplomatic mission with political goals. Russia obtained specific technological knowledge, secured the anti-ottoman coalition, and even gained favor against Sweden, where the confrontation was inevitable. Now the story of the Great Embassy allows us to compare the tsar with the other monarchs of that time and that trip, to wit: King William III, also head of state of the Dutch republics, Elector of Brandenburg Frederick I (later King of Prussia), Holy Roman Emperor Leopold I and King of Poland August II. In the following comparison, we make several remarks regarding King Louis XIV and Silvestro Valier Doge of Venice since France and Venice were also of great importance for Russia. Although the diplomatic tensions between France and Russia made such a visit impossible, Peter I would travel to France later, in 1717. As for Venice, the Streltzi uprising forced the tzar to return immediately regardless of the previously planned visit.

The comparison among the rulers follows a more straightforward scheme than regular use. Instead of the seven criteria for leaders' comparison singled out in "Ashgate Research Companion to Political Leadership" - personality and traits; followers; societal or organizational context; agenda of collective problems; leader's interpretative judgment; the means used and the effects/results (Masciulli, Molchanov and Knight 2016: 5-6), the study relies on three consolidated features - education, vices and virtues, and political views.

Education. Peter I received his formal education in a troubled atmosphere. Most researchers suggest that the primary education for every young prince was unsystematic and reduced to practical training (Шмурло 2008: 280). There was some tutoring 
from various teachers, but a lot depended on self-education and personal life experience through trial and error. Later the lack of proper standardized education was corrected thanks to his confidants like Boris Golitsyn and Andrei Matveev.

Interestingly, the education of Louis XIV shared a similar fate but to a lesser degree. Louis XIV's education was interrupted during the Fronde, so he did not receive the complete humanist syllabus, which might fit a subject for a high office (Treasure 2001: 4). Like Saint-Simon or Druon, some authors went even further, highlighting the complete lack of relevant education regarding the young Louis XIV (Wolf 1972: 5). It is entirely the opposite with Leopold I and William III. The future emperor of the Holy Roman Empire was extremely eager to learn, as witnessed by historians including James Bryce. He eventually became fluent in Latin, Italian, and Spanish and had good knowledge of history, literature, natural science, astronomy, and music. Leopold was a person with deep devotion as one of many qualities, which turned him into the personification of pietas Austriaca (Austrian piety), the loyal Catholic attitude of his House $^{6}$. William III received primarily a theologian education, so the young prince must have known the Reformed doctrine in detail. Later the prince continued his education in Leiden for nearly seven years, studying ethics, philosophy, French, history, etc. (Troost 2005). The education of Frederick I was somewhere in between - it was provided by only two but very well-prepared private tutors.

Vices and virtues. It is hard to determine an individual's core set of values even when many of his deeds are well-known and studied. Still, it is even harder to determine if such qualities are sufficient for the emperor's title. To be "best" and "brightest" is not enough in the world of real politics. Sylvester Valier, for example, did not have the political intelligence of his father or the practical wisdom of the Medicis. Still, he was a handsome man, a good orator, generous to the poor, and magnanimous to ordinary people. He rose steadily from procurator of St Marco (at the age of 19) to appointee at Banco Giro (age of 25), wise man of the Merchandise (age of 31), and so on till the election for Doge in 1694 (at 64). He was not magnificent in any sense but had a noble and dignified profile ideal for the position (Zago 2020). Although there was a dramatic difference between the royal profiles in question, they still shared traits that defined them and even made them closer.

The first one is the enormous ambition for exercising power and to rule through whole imperium - it is most notable in Louis XIV, Carl XII, and Peter I, and only some specific circumstances deprived some of them of that opportunity - Leopold I, William III, Jan III or August II. Secondly, it is the temptation to make reforms. Some of them appeared to be unsuccessful reformers, such as the polish kings, while others like Louis XIV, Leopold I, or Peter I are recognized as great reformers of the $17-18^{\text {th }}$ century. Usually, the success or failure of specific reforms correlates with the political

\footnotetext{
6 Dienst H. 2020. Leopold I. Encyclopedia Britannica. URL: https://www.britannica.com/biography/Leopold-I-Holy-Roman-emperor (accessed 01.11.2021)
} 
will for their implementation directly. Most of the reviewed monarchs had this quality, especially if compared with Charles II of Spain, whose rule put an end to the Spanish Empire as a great power. The third is the lack of fear to resolve strategic problems through military confrontation. The Doge of Venice, for example, rarely even spoke about military intervention. However, all the other monarchs were inclined to wage wars. Some of them proved to be talented military commanders like Carl XII or Jan III Sobieski; many, with Louis XIV, considered war an element of grand strategy; for Peter I or William III, war was a necessity determined geopolitical projections of the neighboring countries. Thus, war as an instrument was a shared characteristic of the reviewed monarchs despite the differences.

Political views. Peter I and his fellow monarchs tended to cement a stable and personal control over the state's affairs and strived to create the image of an enlightened person in the eyes of the people, aristocracy, and their neighbors. The Protestant William III and King Frederick I and the Catholic Jan III, August II, and Leopold I, were very religious (or emphasized religious issues). It is hard to define the exact attitude of Peter I to the church. Like many before him, he regarded it as an instrument of state (by utilitarian approach), and as a result, he stayed in constant confrontation with the clergy. Carl XII was even more disinterested in religious matters and did not take faith into considerations while making his political decisions. These monarchs might be characterized as enlightened autocrats, especially Sun King Louis XIV or "Swedish meteor" Carl XII, who was sometimes called "the lion of the north," "the chosen of God," or recognized as an early archetype for the $18^{\text {th }}$ century enlightened despots ${ }^{7}$. However, in terms of real change, Peter I stood primus inter pares, with his glorious achievements being undisputed despite the contradicting nature of his rule.

\section{Military successes and their nature}

Political leadership is of crucial importance: the imperial structures' emergence, rise, and fall are usually associated with the names of historical figures that remain in the chronicles with their creative or destructive activities. Some of them become a symbol of power and a pattern for political behavior, with contemporaries even recognizing them as true revolutionary forces of history. Their names still provoke controversial debates about personal qualities, role in separate events, and ability to influence the political process. They considered a symbol of the era to be future generations, those who can skillfully combine different qualities that are in tune with the challenges of the epoch. In such a difficult period when the Russian Empire emerged, the head of state was precisely a figure who successfully combined political vision, strategic sense, military abilities, and diplomatic agility. All these qualities of Peter I, combined with

\footnotetext{
7 Dash M. 2012. The Swedish Meteor: The Blazing Career and Mysterious Death of Charles XII. mikedashhistory.com. URL: https://mikedashhistory.com/2012/09/25/the-swedish-meteor-the-blazing-career-and-mysterious-death-of-charles-xii/ (accessed 01.11.2021)
} 
the appropriate historical conditions, were crucial for a new status of the Tsardom of Russia.

As with any significant historical figure, the assessments of Peter I are not - and cannot be - unambiguous. However, it is difficult to dispute that he made a substantial contribution to the transformation of the Russian state into an empire. Although some researchers criticize Peter's reforms as a retreat from the Russian traditions (Карамзин 1991; Платонов 2007), the state's modernization ultimately leads to political and military strengthening of Russia.

One of the drawbacks of the studies focusing on that period is the focus on internal reforms of Peter I as the basis for empire building at the expense of underestimating essential aspects of his foreign policy. As far as Peter's military policy is concerned, historiography is dominated by the Great Northern War as a central event, a core of the Russian strategy. This approach is correct but only from a narrow historical point of view. If the geopolitical instruments are applied, other essential vectors of Russian foreign policy might be seen more clearly. However, these vectors do not always complement each other, although they are related to a common ideological core.

The territorial expansion is a fundamental prerequisite for the emergence of imperial structures. Its realization is usually a priority goal based on will and military success. The operationalization of the "military success" concept seems to be easy because battles and wars, in most cases, can be associated with a specific winner; however, preoccupation with this statement is misleading: there are situations whose potential strategic horizons and operational spaces that can be uncovered even after a military loss have to be considered. Military initiatives of Peter I should also be discussed within this conceptual framework.

Above all, it is necessary to make a specific distinction between the directions of the territorial expansion of the Russian state. Russia developed a particular type of colonization to the east and southeast, which can be defined as a mixed type between imperial power colonialism, settler colonialism, and extractive colonialism. None of the types existed in their pure form (Shoemaker 2015). However, for several reasons, one can argue that the striving for a territorial expansion of Russia to the east was not only economic since it was also aimed to ensure security regardless of the initial economic motivation. In contrast to the Western type of territorial expansion, in the Russian case, there were no natural obstacles between Russia and distant unknown lands - seas, oceans, insurmountable mountains, that made the full possession of these lands a primary factor of security.

The territorial expansion to the west and southwest did not follow this logic because the uncertainty was minimized here, and the opponents were well known. Instead, it was a traditional enlargement based on military clashes between states whose geopolitical fields partially overlapped, and the right to own the territory was determined by force between relatively equivalent actors (Окунев 2019: 229-231). Two specific factors influenced the geopolitical context. Firstly, the states bordering the Tsardom of Russia, including the Habsburg and Ottoman Empires, were developing as 
continental states and had no purposeful interest in conquering overseas territories. Secondly, those circumstances predetermined their aspiration for access to the sea, not falling into economic isolation from the fast-growing maritime market, also maintaining the navy as a resource of imperial power.

\section{Peter's Azov campaigns, 1695-1696}

At the beginning of Peter's reign, Russia was practically isolated from the World Ocean. Among the major continental powers in the region, only Russia had no access to the sea. The Black Sea was almost inland to the Ottoman Empire, and Sweden controlled the Baltic Sea, so these two directions became a strategic choice for Peter I.

The Eastern European countries were engaged in protracted bloody battles in the Holy League War with the Ottoman Empire. Furthermore, the Nine Years War was in full swing across the west, engaging the Habsburg Empire's forces on multiple fronts. These circumstances influenced Peter's decision to reach the Black Sea. The Ottoman Empire was militarily engaged on the Eastern European front; Russia participated in the Holy League, so practically, the two countries were in a state of war. The Ottoman Empire seemed to be a more suitable adversary than Sweden; moreover, it was the secondary front for the Sublime Port; therefore, Peter initiated his Azov campaigns (Стоянов 2018: 141-143).

Giving today's assessment to Peter's decision is not so easy. In terms of historical realities, it was correct. From a practical point of view, the control of Azov did not provide open access to the sea since the Kerch strait, the Bosporus, and the Dardanelles remained under the control of the Ottoman Empire, restraining the operational capabilities of a potential Russian Azov fleet. Geopolitically the strong presence in the Black Sea was possible only through the possession of the Crimean Peninsula, so probably that was a reason why the Azov campaigns did not receive a detailed assessment. There is again a tendency to downplay the strategic importance of the conquest of Azov because of its returning to the Ottoman Empire in just over a decade. Then what was Peter's military success in the Azov campaigns?

Military affairs can easily fall into the trap of dichotomous "victory-loss" thinking. When analytical tools are applied, both "results" might have unequal long-term consequences. The Azov campaigns represent a striking example of that because the military success of the de facto conquest of Azov did not bring serious strategic advantages. Still, Peter managed to learn the necessary lessons and took actions that, in the longturn perspective, would make the Azov campaigns a critical success in the process of transformation of Russia into a great power.

First comes the thesis of the birth of the Russian navy that has already become a cliché. Of course, it is naive to think that the navy emerged only thanks to Peter I, but during his rule, ship manufacturing became a purposeful and coordinated state policy. The modest navy that had been built for sure was not able to compete with the naval forces of the Ottoman Empire. Still, it finally cemented the belief that Russia was 
doomed to remain an isolated regional power without a strong navy. In that sense, Peter took the first step towards going beyond the conceptual understanding of Russia as a land power.

Secondly, immediately after the conquest of Azov, Peter ordered the first naval base - Taganrog - to be established. Despite the limited operational capabilities of the Azov Sea (since it did not provide direct access to the World Ocean), access to the sea significantly affected the development of the Russian fleet, both technologically and in terms of its use. The importance of naval bases for power projection in neighboring and far regions was correctly recognized. At the same time, from the point of view of classical geopolitics, there is a significant difference in the attitudes of "land" and "sea" powers to the navy usage. Peter I understood the importance of maintaining a permanent fleet in the Sea of Azov as a key element in controlling the surrounding area and approaching the Volga region and the Caucasus.

Thirdly, the Azov campaigns revealed many weaknesses in the Russian army, which in the long run allowed Peter to undertake the necessary reforms to meet the requirements of the coming geopolitical confrontation. That was not just about another reform, but about the feeling that the army should be a permanent and professionally built element of imperial power, a kind of mandatory attribute whose functioning must follow strict rules and regulations. Thus, after the conquest of Azov and the Streltsy uprising in 1698, Peter began one of his most outstanding reforms - the transformation of the Russian army into a stable institution of the future Empire and an essential component of Russian foreign policy.

The real military significance of the Azov campaigns lies in the listed achievements, which eventually changed the image and status of the Russian state. In addition, with the conquest of Azov, Russia declared to the other powers its Black Sea geopolitical interests. Its new positions on the Black Sea coast changed the manner of interaction with the Tatars, Cossacks, and other local peoples. All of that was a longterm consequence of the Azov campaigns. The achievements were skillfully used to establish a new geopolitical status of the Russian Empire.

\section{The Great Northern War}

A central part of the Peter's reign was the Great Northern War, which occupied more than half of his rule. Peter also relied on diplomatic efforts to create a stable alliance of states interested in weakening the adversary and creating conditions for territorial redistribution. In the war against Sweden, however, Peter took on the responsibility to be a core of the alliance, which significantly affected the scale of the conflict for the Russian side.

Russia has several strategic aims in the war against Sweden. First, it strived to reach the sea on the nearest land corridor - Karelia, Ingria, Estonia, Livonia - by pushing out the Swedes. The other Baltic powers were also interested in limiting Sweden's influence, but not at the expense of Russia's strengthening. However, Peter's 
personal qualities allowed him to build trust with the Danish and Polish-Lithuanian kings.

The second crucial political value of this geostrategic direction was the possibility of increasing Russian influence in the Rzeczpospolita. In addition to mutual interests concerning Sweden, Peter skillfully used his influence on August II (Анисимов 2009: 228) to implement Russia’s plans for getting access to the sea. Furthermore, good relations with Denmark and the Polish-Lithuanian Commonwealth favored Russia's future connection with the World Ocean to avoid "the Azov paradox," in which access to the sea did not guarantee operational maritime space.

The third perspective was the possibility of strengthening Russia's position in the Left-bank Ukraine in case of successful developments in the war against Sweden and stable relations with the Polish-Lithuanian Commonwealth. This territory was a secure springboard for a future operational corridor to the vassals of the Ottoman Empire - the Orthodox principalities of Wallachia and Moldova were considered to be the sphere of Russian interests.

Only after the temporary neutralization of the Ottoman threat did all these strategic perspectives related to the war with Sweden come to the fore. What were the prerequisites compared to the war against the Ottoman Empire? The main direction of the Ottoman expansion was Eastern and Central Europe, which determined the strategic importance of this front. In this sense, the Azov front was a second direction in which a tactical retreat was more possible. The Ottoman Empire's defeats on the main front took it out of the playing field for a short time, and Peter I skillfully took advantage of that situation.

On the other hand, the Baltic was a priority for Sweden, which undoubtedly confronted this geopolitical vector. Control over the Baltic Sea area gave strategic advantages and made Swedish foreign policy a key factor in the region. At the beginning of the war, Sweden had undergone a relatively long period of peace and, unlike the Ottoman Empire, had far fewer potential conflict lines and fronts.

In this sense, the Northern Alliance appeared to be necessary to engage more armed forces and the strategic plan to divide the Swedish military capabilities into several fronts. However, the other states remained unprepared to meet that response, and Russia must have taken the main strike, which transformed the first phase of the war into a classic Russian-Swedish clash for spatial control of the eastern Baltic coast. Surprisingly or not, the Swedish army showed a profound superiority, which, like the Azov campaigns, positively affected the depth and speed of military reforms undertaken in Russia.

The strategic plan to divide the Swedish forces was realized. Charles XII wasted a lot of time in the Rzeczpospolita and gave Peter a chance to complete the most necessary reforms in his army. Despite the conventional wisdom that in historical research, one cannot use the conditional mood, from the comparative perspectives for both armies and of the possible scenarios, it is logical to ask, what would have happened if Charles XII had not lost so much time in the Rzeczpospolita or if he had gone into a strategy of exhausting defense? 
Since the attempt to access the sea in the short run failed, the war entered "a waiting phase," looking for a decisive battle. For a long time, however, both sides avoided this. The conflict transformed into a proxy war in the Rzeczpospolita civil conflict, where Russia and Sweden supported different parties. After the conquest of the PolishLithuanian state, Carl XII had two options: to launch a swift attack against Russia or to strengthen positions and start a war of attrition.

The second scenario certainly seemed to be better, for it was only a matter of time before the Ottoman threat from the south would return and significantly increase Sweden's chances for success. Finally, however, the young Swedish King decided to take a dramatic step that hardly surprised the experienced and cautious Peter. Entering Russian territory turned out to be a severe mistake unless the hypothetic preliminary agreement with the Ottoman Empire and its allies would be accepted.

Peter's victory at Poltava in 1709 is undoubtedly his most tremendous military success, not only from the point of view of military history. The consequences of the Battle of Poltava satisfied all the strategic prospects of the Russian state stated on the eve of the war with Sweden - the open way to the Baltic Sea, regained influence on the Rzeczpospolita and the Cossacks. That cemented Russia's positions in Eastern Europe, so it was only a matter of time before the war ended with Sweden's final defeat.

However, the upset strategic balance of power in Europe "required" its restoration. Simultaneously with the Great Northern War, the western part of the continent was also engulfed in a violent military conflict in which the Habsburgs and the Bourbons claimed the Spanish crown. Those commitments temporarily removed the Habsburg Empire from military struggles in Eastern Europe, allowing the Ottoman Empire to recover from protracted wars and seek revenge on Russia engaged in a war for a decade. Apart from that, the Ottoman-Habsburg border consisted of a well-secured military zone and hard-to-reach Carpathian mountain range, making that adversary undesirable and relatively predictable.

Aspiring to restore the balance of power, Sweden and the Ottoman Empire were natural allies, and it was determined not so much by the diplomatic efforts as by the very logic of political processes in Europe. The Russo-Ottoman War of 1710-1713 and the Pruth Campaign, in particular, have been sometimes criticized by researchers, especially in the context of the protracted war with Sweden. However, it was unlikely that Peter I and the Russian military and political elite would have taken action to provoke a resumption of hostilities with the Ottoman Empire if that had not been a preventive reaction against strengthening the Swedish-Ottoman-Tatar alliance. It was challenging to find a profound strategic idea in the decision of Ahmed III to go to war with Russia. As the war results demonstrated, the consequences were rather tactical, aimed at revenge and an attempt to partially restore the balance of power in the southern direction at the expense of Russia's enlargement to the Baltic.

In this context, the allies of the Ottoman Empire, Charles XII and Devlet II Giray could not have been satisfied with the course of events because they planned to push out Russia and seek a decisive battle that would at least restore the pre-war status quo. 
Therefore, the independent consideration of the war between Russia and the Ottoman Empire of 1710-1713 might lead to misleading conclusions based on wrong assumptions and disregard for the geopolitical macro-framework. However, when this war is considered within the general historical and political context, many questions find their answers through basic concepts of international relations theory.

By that logic, a large part of the criticism of Peter I regarding the Pruth Campaign could be mitigated. It might also clarify why the Ottoman Empire, despite its advantages, had limited demands on Russia. In addition, following the mechanism of bilateral dispute resolution established by tradition in international relations of that time, the interests of Sweden, the Crimean Tatars, and the Cossacks were not protected as expected. On the contrary, although he lost Azov and had to destroy Taganrog, Peter secured the Sublime Porte's tacit consent to preserve the gains since the beginning of the Great Northern War. Thus, Azov was a price Peter had to pay to secure his rear, allowing him to achieve more important strategic goals for Russia.

The Great Northern War continued for another eight years after signing the Adrianople Peace Treaty between Russia and the Ottoman Empire in 1713. That period was used to revise relations with the European countries and seek diplomatic support for the postwar status quo. The number of states involved in the potential territorial redistribution increased during the last phase of the war. Therefore, the system of treaties (Treaty of Nystad, Treaty of Frederiksborg, and Treaty of Stockholm) that ended the Great Northern War had a cumulative impact on the future of the Russian Empire.

First, those treaties ended Swedish domination in Northern Europe and the Baltic Sea, leading to the gradual erosion of Sweden's power in general. This process created a geopolitical vacuum in the regions, which did not fall within the strategic priorities of the great European powers. It was the main prerequisite for transforming the northern direction into one of the leading Russian foreign policy vectors in the coming years, guaranteeing Russia's political, economic, and cultural ties with the rest of the world.

Second, the new horizons for political expansion laid the stable foundations for the emergence of the Russian Empire. In this sense, in addition to the spatial element, the assimilation or inclusion of new peoples with their cultural and religious values should also be mentioned. This complemented the diversity of the Russian state and strengthened its imperial status. Finally, the transformation of Russia into a major power in the Baltic and the stabilization of the new Russian geopolitical vector encouraged its beneficial participation in the partitions of the Polish-Lithuanian Commonwealth in the second half of the 18th century.

The Treaty of Nystad turned Russia into a leading Baltic state and one of the great powers in Europe. That status would be maintained by Catherine II and defended during the Napoleonic Wars by Alexander I (Figure 2). The end of the Great Northern War allowed Russia to complete its imperial transformation, securing its strategic interests. One year after the Peace of Nystad, Peter I initiated the Persian campaign. In the Caucasus-Caspian geopolitical triangle, Russia, the Ottoman Empire, and the Safavid state clashed for seeking redistribution of territories and more political influence. 


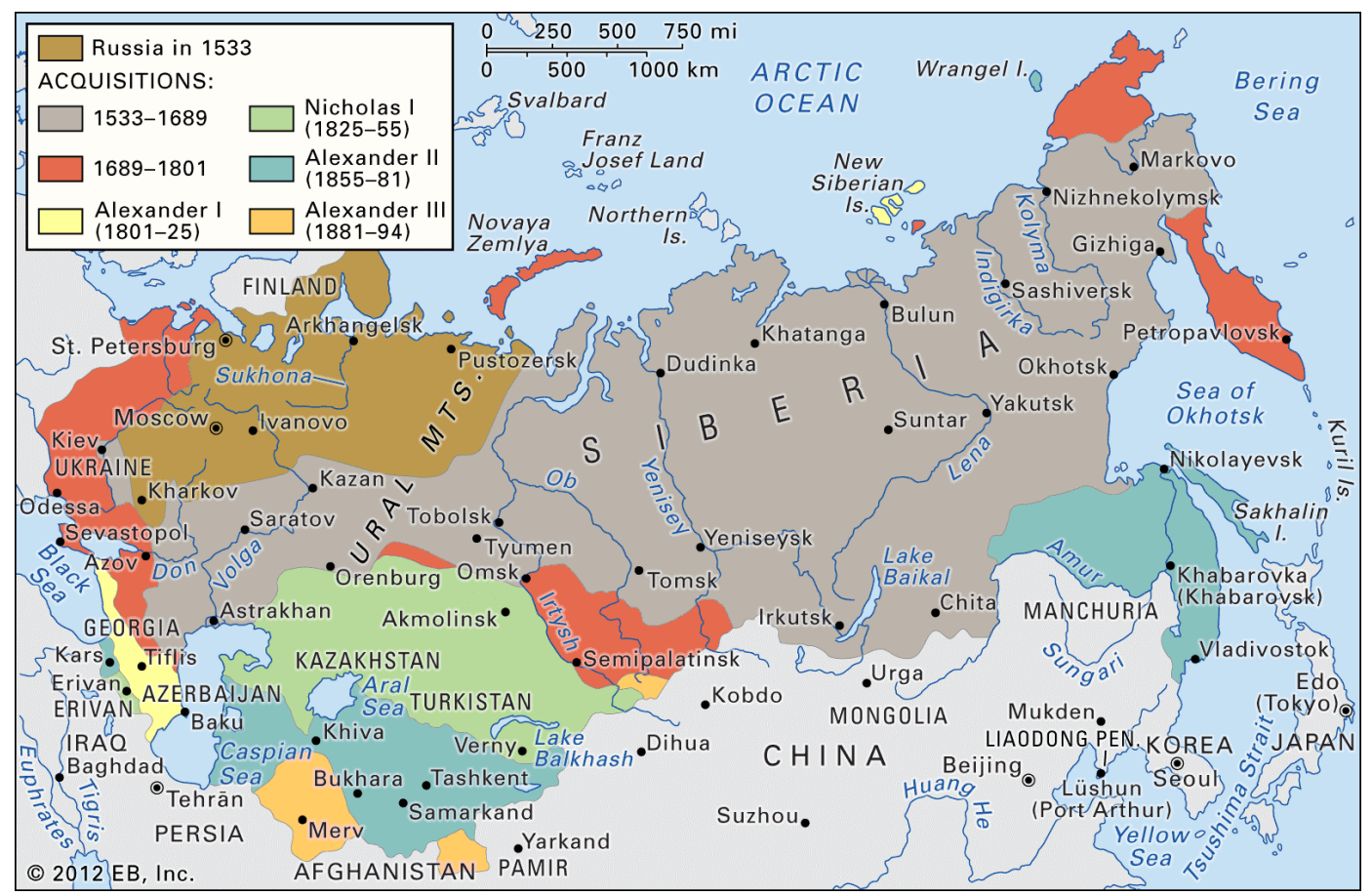

Figure 2. Russian Empire, expansion in Asia and Europe

Source: Encyclopædia Britannica, Inc.

Peter I managed to conquer the strategic zone around Derbent, which took a central place for trade along the north-south line, and subsequently gained control over the west coast of the Caspian Sea. Even though those territories remained in Russian possession just for several years, in this campaign, Peter consolidated the third vector of Russian strategic interests - the Caucasus. In many respects, this legacy - the priority of Baltic, Black Sea, and Caucasus directions of Russian foreign policy - remains the dominant factor to this day. In the following centuries, these directions remained the most important venues of the territorial expansion of the Russian Empire.

It would hardly be an exaggeration to say that Peter's imperial policy had a lasting influence not only in Russian foreign affairs but also in many symbolic aspects of its domestic politics - a combination that few in history have succeeded in achieving. Peter I played a significant role in the emergence of the Russian Empire as we knew it in the following centuries. Moreover, his political legacy clearly shows that the great statesman must have a broad outlook, be consistent and learn from mistakes. Compared to his fellow monarchs from the end of the $17^{\text {th }}$ and the beginning of the $18^{\text {th }}$ centuries, Peter I met the high imperial standards set by the rulers of the epoch. Despite his ups and downs, he rose to the glory of a true basileus kai autokrator and established a political tradition for the future generations of Russian tzars. 


\title{
About the authors:
}

Aleksandar Dimitrov - PhD (Political Science), Lecturer at the Department of Political Science, University of National and World Economy, 1700 Sofia, Student Town, UNWE, Sofia, Bulgaria. E-mail: a_dimitrov@unwe.bg

Galin Durev - PhD (Political Science), Professor at the Department of Political Science, Sofia University St. Kliment Ohridski, Tsar Osvoboditel Blvd. 15, Sofia, 1504, Bulgaria. E-mail: galindurev@gmail.com

\section{Conflict of interests:}

The authors declare the absence of any conflict of interests.

\section{Пётр I и рождение Российской}

\section{империи: политическое лидерство}

\section{и военные успехи в сравнительной перспективе}

\author{
А. Димитров ${ }^{1}$, Г. Дурев ${ }^{2}$ \\ DOI 10.24833/2071-8160-2021-6-81-71-88 \\ ${ }^{1}$ Университет национального и мирового хозяйства (Болгария) \\ ${ }^{2}$ Софийский университет «Св. Климент Охридский» (Болгария)
}

Для становления империи обычно необходимы международно-политическое признание и масштабные военные успехи. Решающее значение для формирующейся империи имеют также личность правителя и действия его политических и военных советников и генералов. Авторы статьи утверждают, что в случае с Петром Великим (Петром Первым) политическое признание и военные успехи происходили одновременно, распространяясь на восточные и западные рубежи, но вместе с тем реализуясь в разных геополитических контекстах. В статье проводится ряд сопоставлений между Петром I и другими монархами той эпохи, такими как Карл XII, Август II, Фредерик I, Карл II, Виллем III и Леопольд VI, по трём критериям - уровень образования, «добродетели и пороки», а также политические взгляды. Необходимость подобного сравнительного анализа обусловлена тем, что сделанные выводы позволяют выделить основные факторы в личностном становлении Петра, которые оказали решающее воздействие на его политику. Кроме того, в статье свою оценку получают военная политика и победы Петра. Военные достижения царя напрямую коррелируют со становлением России в качестве империи и великой державы. В результате подписания Ништадтского мира были защищены основные геополитические интересы России, а территория империи получила свои очертания на последующее столетие. Кроме того, территориальное расширение привело и к реализации во внутренней политике модели «imperium», которая обеспечила абсолютную власть российских монархов. Авторы подчёркивают связь между личностным развитием монархов, их политическими достижениями и имперскими 
амбициями. Сравнительный анализ данных факторов в различных кейсах позволяет прийти к новым выводам в понимании того исторического периода.

Ключевые слова: Пётр I, империя, империй, лидерство, геополитика, война, Ништадтский мирный договор, Северная война

\section{6 aвmopax:}

Александр Димитров - кандидат политических наук, преподаватель кафедры политологии, Университет национального и мирового хозяйства, София, Болгария.

E-mail: a_dimitrov@unwe.bg

Галин Дурев - кандидат политических наук, кафедра политологии, Софийский университет «Св. Климент Охридский», София, Болгария. E-mail: galindurev@gmail.com

\section{Конфликт интересов:}

Авторы заявляют об отсутствии конфликта интересов.

\section{References:}

Bryce J. 1901. The Holy Roman Empire. Phototype ed. New York: Macmillan \& Co. 575 p.

Dimitrov A. 2020. The Concept for Leader and Leadership in the Proto-Studies of Leadership. The European Tradition. Yearbook of UNWE. № 1. Sofia: UNWE Publishing. P. 65-87.

Howe S. 2002. Empire - A Very Short Introduction. Oxford University Press. 160 p.

Masciulli J., Molchanov M., Knight W. 2016. The Ashgate Research Companion to Political Leadership. Abingdon: Routledge.

Seal G. 2001. Encyclopedia of Folk Heroes. Santa Barbara, Cal: ABC CLIO. 357 p.

Shennan M. 1995. The Rise of Brandenburg Prussia. London: Routledge. 75 p.

Shoemaker N. 2015. A Typology of Colonialism. Perspectives of History. 53(7).

Soloviev S. 1994. History of Russia. Peter the Great - a Reign Begins, 1689-1703. Vol. 26. Florida: Academic International Press.

Stiles M. 1999. John III Sobieski. The 17th and 18th Centuries: Dictionary of World Biography. Vol. 4. By Frank Magill (ed.). London: Routledge. 1534 p.

Takacs S. 2008. The Construction of Authority in Ancient Rome and Byzantium. The Rhetoric of Empire. New York: Cambridge University Press. 167 p.

Treasure G. 2001. Louis XIV. New York: Routledge. 388 p.

Troost W. 2005. William III, the Stadholder-King. A Political Biography. Ashgate Publishing. $361 \mathrm{p}$.

Whaley J. 2012. Germany, and the Holy Roman Empire. Volume 2 from the Peace of Westphalia to the Dissolution of the Reich (1648-1806). New York: Oxford University Press. 784 p.

Wolf J. 1972. Louis XIV. A Profile. London: The Macmillan Press. 265 p.

Zago R. 2020. Sylvester Valier. Biographical Dictionary of Italians. Vol. 98.

Zamoyski A. 2014. The Last King of Poland. Endeavour Press Ltd.

Стоянов А. 2018. Руско-турските войни 1569-1878. София: Сиела. 504 с.

Шмурло Е. 2008. История на Русия IX-XX век. София: Рива. 560 с.

Anisimov E. 2009. Istoriya Rossii ot Ryurika do Putina [History of Russia from Rurik to Putin]. Saint Petersburg: Piter. 592 p. (In Russian) 
Karamzin N.M. 1991. Zapiska o drevney i novoy Rossii v yeye politicheskom i grazhdanskom otnosheniyakh [A Note on Ancient and New Russia in Its Political and Civil Relations]. Moscow: Nauka. Glavnaya redaktsiya vostochnoy literatury. 127 p. (In Russian)

Okunev I. 2019. Politicheskaya geografiya [Political Geography]. Moscow: Aspekt Press. 512 p. (In Russian)

Platonov S.V. 2007. Istoriya Rossii. Polnyy kurs lektsiy po russkoy istorii [History of Russia. A Complete Course of Lectures on Russian History]. AST. 816 p. (In Russian)

\section{Литература на русском языке:}

Анисимов Е. 2009. История России от Рюрика до Путина. Санкт-Петербург: Питер. 592 c.

Карамзин Н.М. 1991. Записка о древней и новой России в ее политическом и гражданском отношениях. Москва: Наука. Главная редакция восточной литературы. 127 с.

Окунев И. 2019. Политическая география. Москва: Аспект Пресс. 512 с.

Платонов С.В. 2007. История России. Полный курс лекций по русской истории. АСТ. $816 \mathrm{c}$. 